Acta vet. scand. $1977,18,515-521$.

From the Department of Pathology, Veterinary College of Norway, Oslo.

\title{
LIQUOID-INDUCED ARTERIAL LESIONS AND THE GENERALIZED SHWARTZMAN REACTION
}

By

Knut Nordstoga

\begin{abstract}
NORDSTOGA, KNUT: Liquoid-induced arterial lesions and the generalized Shwartzman reaction. Acta vet. scand. 1977, 18, 515-521. - Mural necrotic lesions were produced in renal afferent arteries in rabbits, pigs and blue foxes, by intravenous injections of Liquoid. These lesions were frequently accompanied by thrombosis in the affected arterial segments and invariably by "microthrombosis" in glomerular capillaries. Mural arterial lesions were always present in cases with evident macroscopic necrotic changes of the renal cortex. Necrotic arterial lesions, with thrombosis, were also observed in pulmonary arteries in all the animal species used in these experiments, i.e. rabbit, pig, blue fox, mouse and ferret.
\end{abstract}

Liquoid; arterial lesions; microthrombosis;

thrombosis; necrotizing angiitis; general

Sh w a r z m a reaction.

In a series of previous studies we have stressed the occurrence of necrotizing mural arterial lesions in animals of various species submitted to an experimental procedure of the Shwartzman type (Nordstoga \& Fjølstad 1967, 1970, 1973, Teige et al. 1973). Although bilateral renal cortical necrosis (BCN), the identifying lesion (Thomas \& Good 1952) of the generalized Shwartzman reaction (GSR), cannot be produced in all experimental animals, necrotizing angiitis, frequently accompanied by thromboses, is regularly found in individuals of all species, the lungs being target organs besides the kidneys.

The GSR is, classically, induced in rabbits by 2 subsequent intravenous injections of bacterial endotoxin, spaced $24 \mathrm{hrs}$. apart (Thomas \& Good, McKay 1965). In our previous experiments, 
bacterial products, either disintegrated cells of Gram negative bacteria, or commercial endotoxin, were used to provoke the GSR. Liquoid, a synthetic acid polymer (sodium polyanethol sulphonate), has also been used for the experimental induction of the renal Shwartzman reaction (Evensen et al. 1967, Rodriguez-Erdmann et al. 1960). In this report, which is based on patho-morphological examinations of organs of experimental mammals of 5 different species, it is shown that necrotizing mural arterial alterations, and thrombotic lesions, are also present in the kidneys and the lungs when the GSR is elicited by Liquoid. As overt necrotic changes in the arterial walls were seldom seen outside these organs, only renal and pulmonary alterations are described.

\section{MATERIALS AND METHODS}

\section{Preparation}

Liquoid (F. Hoffmann-La Roche, Basel, Switzerland) was dissolved in sterile saline, at a concentration of $4 \mathrm{mg} / \mathrm{ml}$, frozen, and thawed immediately before use. Single doses were used except for 2 pigs which were given 2 injections, with an interval of 24 hrs.

\section{Experimental animals}

Ten young rabbits (Oryctolagus cuniculus), weighing approx. $1 \mathrm{~kg}$, were injected intravenously (i.v.), doses: $15-20 \mathrm{mg} / \mathrm{kg}$ body weight (b.w.). A young pig (Sus scrofa) weighing about $15 \mathrm{~kg}$, was injected i.v. with $13 \mathrm{mg} / \mathrm{kg} \mathrm{b.w.;} 2$ other pigs, weighing about 10 and $15 \mathrm{~kg}$, received 2 separate injections each, the total amount of Liquoid being 40 and $35 \mathrm{mg} / \mathrm{kg}$ b.w., respectively. Ten blue foxes (Alopex lagopus), of both sexes, the ages varying from about 5 months to 3 years and 5 months, were injected i.v., doses : $4-12 \mathrm{mg} / \mathrm{kg}$ b.w. Ten adult ferrets (Mustela putorius furo), were injected intracardially, doses: $15 \mathrm{mg} / \mathrm{kg}$ b.w. Thirty mice (Mus musculus), weighing $20-30 \mathrm{~g}$, were injected i.v., doses: $0.2-1.6 \mathrm{mg} /$ animal.

Surviving animals were killed 24-72 hrs. after treatment. Pieces of organs were fixed in $\mathbf{1 0} \%$ buffered formalin and sections stained routinely with haematoxylin and eosin (H \& E). These additional stains were used on selected sections: elastin 
van Gieson, Lepehne's haemoglobin staining method, phosphotungstic acid haematoxylin (PTAH), Martius scarlet blue (MSB) and the Lendrum's acid picro-Mallory method (Lendrum et al. 1962).

\section{RESULTS}

Varying degrees of respiratory distress were observed after the administration of Liquoid in animals of all species; during the first half hour all pigs had repeated vomiting.

Seven rabbits died within $7 \mathrm{hrs}$. after the injections of $\mathrm{Li}$ quoid; 8 foxes died 18-44 hrs. after the infusions; 4 ferrets died within a few minutes-21/2 hrs., and 16 mice died $15 \mathrm{~min}$.48 hrs. after treatment.

\section{Necropsy findings}

Rabbits. Seven of the rabbits showed renal cortical lesions, varying from scattered haemorrhagic foci to total BCN.

Pigs. The largest of the pigs, which was given 2 i.v. infusions of Liquoid, had scattered wedge-shaped lesions in the cortical layer of both kidneys, with the macroscopic appearance of typical infarcts.

Blue foxes. Five of the 8 animals which died during the experimental period had a characteristic uneven, blotchy colouration of the external surface of the kidneys.

Mice and ferrets. The only renal alterations were varying degrees of congestion.

A considerable number of individuals from all species had pale, emphysematous pulmonary tissue, with scattered haemorrhagic areas.

\section{Microscopic renal lesions}

Rabbits. In animals exhibiting evident macroscopic renal changes, the major part of the cortical layer was entirely necrotic, although a narrow subcapsular rim was spared; in the border zone between the outer intact tissue and the necrotic parenchyma there were heavy infiltrations of leucocytes, many of which were eosinophils. There was always severe endothelial damage within the necrotic areas, and necrotic lesions in the arterial walls, frequently accompanied by thrombosis. Interlobular arteries and afferent glomerular arterioles were most 
constantly affected, but incipient lesions were also sporadically present in arcuate arteries. Homogenous deposits, which frequently had staining properties as fibrin, were commonly present in the glomerular capillaries (Figs. 1-4).

Pigs. In the necrotic areas which occurred in the renal cortex of one of the animals, the microscopic picture corresponded closely to that of typical infarcts (Fig. 5), the vascular changes being similar to those occurring in rabbits.

Blue foxes. In the cortical parenchyma there were incipient degenerative lesions, but total necrosis was not present. Hyaline deposits occurred in the glomerular capillaries in 9 animals, although the amount of precipitation varied somewhat. In $\mathbf{H} \& \mathbf{E}$ stained sections, the material usually had a strongly eosinophilic appearance, as intact red cells, while it was commonly stained red, as fibrin, in sections stained with the MSB method (Figs. 6-7); in PTAH sections the material was, as a rule, stained brownish; it stained brown, as erythrocytes, or sometimes pale greyish-brown with Lepehne's staining method for haemoglobin. There was sometimes endothelial injury, and incipient necrotic lesions in the walls of interlobular arteries and afferent glomerular arterioles, with early thrombosis, but widespread arterial alterations were lacking in this species.

Mice and ferrets. Evident mural vascular lesions were absent in these species.

\section{Microscopic pulmonary lesions}

Septal capillaries were frequently dilated and stuffed with red cells; this phenomenon was most obvious in blue foxes, where also a hyaline, eosinophilic material, with staining properties as the hyaline material in the glomerular capillaries, occluded the minute vessels, in addition to the closely packed, but morphologically intact erythrocytes (Fig. 8). Extravasation of red cells was a common finding.

Endothelial damage and mural arterial changes, with thrombosis, were common findings in animals of all species, except for in mice, where such lesions were only sporadically observed. The necrotic arterial walls were often infiltrated by inflammatory cells, including some eosinophils (Fig. 9); damaged vessels were also sometimes surrounded by cellular infiltrations. Thrombosis was also observed in veins occasionally. 


\section{DISCUSSION}

Single intravenous injections of Liquoid produced renal lesions, compatible with the GSR in rabbits in the present experiment. This finding is in accordance with earlier observations in other laboratories (Rodriguez-Erdmann et al. 1960, Evensen et al. 1967). There were, however, considerable species differences in the morphological renal response to systemic application of Liquoid, and total BCN could not be induced in animals other than rabbits; in this species there was, as in spontaneous cases of BCN, and also in association with individual infarcts induced by mechanisms unrelated to the GSR, a thin subcapsular rim of intact cortical parenchyma.

It may be concluded from the present investigation that endothelial damage, and necrotizing mural lesions of varying severity, frequently accompanied by thrombosis, are always present in the interlobular arteries in cases with obvious gross renal changes provoked by Liquoid; it is also shown that there is frequent involvement of pulmonary arteries, both in animals with renal lesions, and also in animals without kidney alterations. The interpretation of the lung vascular alterations occurring in animals submitted to an experimental procedure of the Shwartzman type is dealt with in a previous article (Nordstoga \& Fjølstad 1975).

It seems clear that Liquoid in experimental situations exerts a "toxic" effect on the vascular walls, either directly or indirectly, an effect that parallels that of bacterial compounds in the elicitation of the GSR. The importance of this observation as to the pathogenetic mechanism in the fulminant renal Shwartzman lesions (i.e. bilateral cortical necrosis), is discussed in a following paper (Nordstoga 1977).

\section{REFERENCES}

Evensen, S. A., M. Jeremic \& P. F. Hjort: Intravascular coagulation with generalized Shwartzman reaction induced by a heparinlike anticoagulant (Liquoid). Thrombos. Diathes. haemorrh. (Stuttg.) 1967, 18, 24-39.

Lendrum, A. C., D. S. Fraser, W. Slidders \& R. Henderson: Studies on the character and staining of fibrin. J. clin. Path. 1962, 15, $401-413$.

McKay, D. G.: Disseminated Intravascular Coagulation. An Intermediary Mechanism of Disease. Hoeber Medical Division, New York 1965. 
Nordstoga, $K .:$ The sequence of events in the development of bilateral renal cortical necrosis accompanying the generalized Shwartzman reaction. Acta vet. scand. $1977,18,522-531$.

Nordstoga, K. \& M. Fjølstad: The generalized Shwartzman reaction and Haemophilus infections in pigs. Path. Vet. 1967, 4, 245-253.

Nordstoga, K. \& M. Fjølstad: Porcine salmonellosis. II. Production of the generalized Shwartzman reaction by intravenous injections of disintegrated cells of Salmonella cholerae-suis. Acta vet. scand. $1970,11,370-379$.

Nordstoga, K. \& M. Fjølstad: Necrotizing angiitis produced by the Shwartzman mechanism. Acta path. microbiol. scand. Sect. A, 1973, 81, 775-783.

Nordstoga, K. \& M. Fjфlstad: Pulmonary vascular lesions in chickens following intravenous injections of disintegrated cells of Escherichia coli. Acta path. microbiol. scand. Sect. A, 1975, 83, 283291.

Rodriguez-Erdmann, F., H.-J. Krecke, H. G. Lasch \& A. Bohle: Uber die morphologischen und gerinnungsanalytischen Veränderungen nach Liquoid. Ein Beitrag zur Pathogenese des SanarelliShwartzman-Phänomens. (On the morphological and coaguloanalytical changes after Liquoid. A contribution to the pathogenesis of the Sanarelli-Shwartzman phenomenon). Z. ges. exp. Med. 1960, 134, 109-130.

F ig u re 1. An arcuate artery of a rabbit, died 5 hrs. after treatment; there is early thrombosis in the lower part of the vessel. Dose: $15 \mathrm{mg}$ Liquoid/kg body weight. H \& $\mathrm{E}, \times 425$.

Figure 2. A glomerulus, with afferent arteriole; from a rabbit killed $24 \mathrm{hrs}$. after treatment. In the vessel luminae, there is an occlusive material stained as fibrin. There is also fibrinoid necrosis of the arteriolar wall. Dose: $15 \mathrm{mg}$ Liquoid/kg body weight. PTAH, $\times 425$.

F i g u re 3. Cortical tissue of a rabbit, killed 24 hrs. after the injection; there is a narrow subcapsular rim of intact parenchyma, and extravasations of red cells in the interstitium. In a border zone between the outer intact tissue and the underlying necrotic parenchyma there are accumulations of nuclear debris and eosinophils. A glomerulus with homogenous deposits in the capillaries can be seen to the bottom left (arrow). Dose: $15 \mathrm{mg} \mathrm{Liquoid/kg} \mathrm{body} \mathrm{weight.}$ $\mathrm{H} \& \mathrm{E}, \times 180$.

Figure 4. Higher magnification of a glomerulus from the same animal as in Fig. 3 ; in the upper part of the figure there are tubular necrosis and incipient infiltration of eosinophils. $\mathrm{H} \& \mathrm{E}, \times 425$. 
K. Nordstoga: Liquoid-induced arterial lesions.

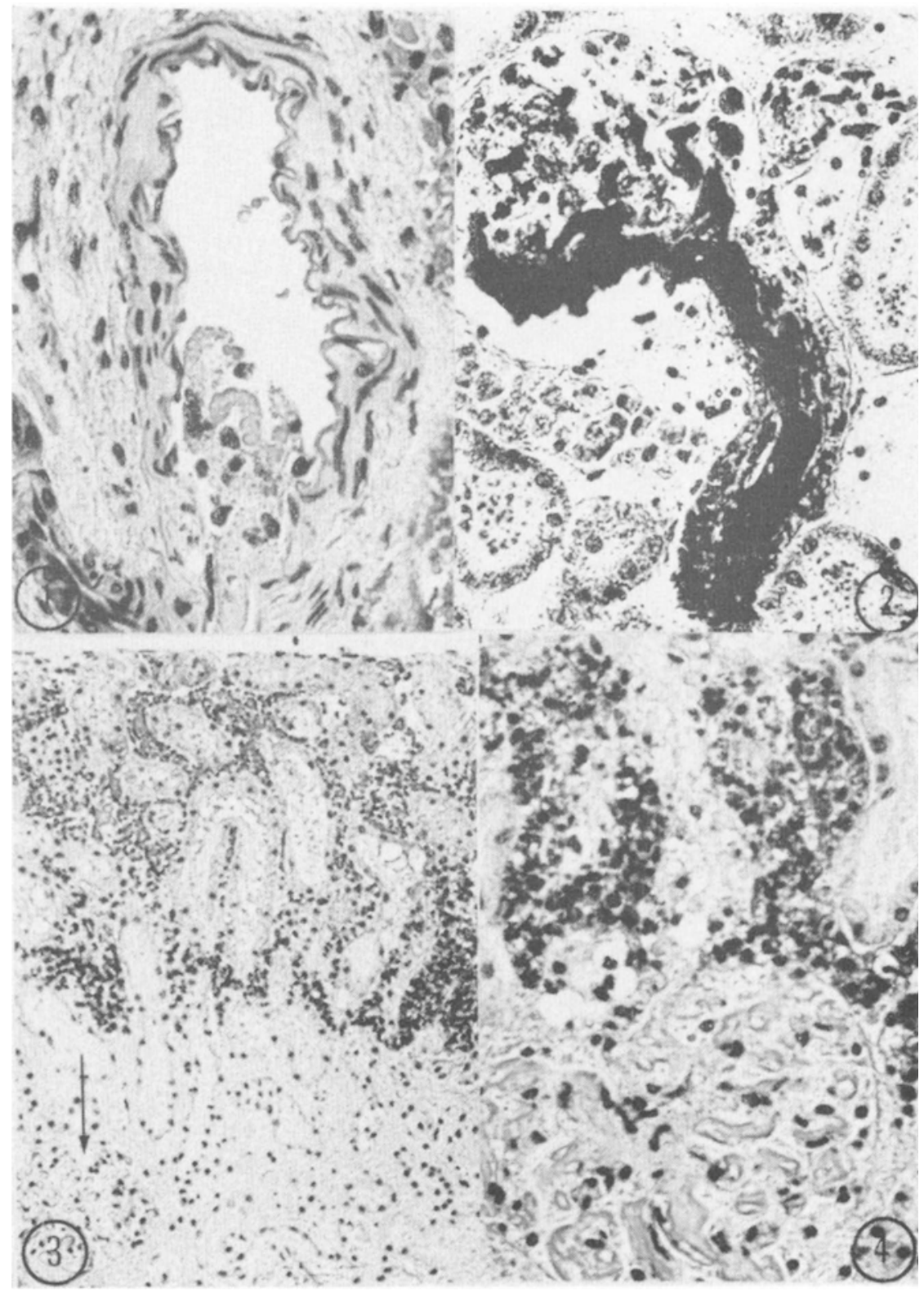




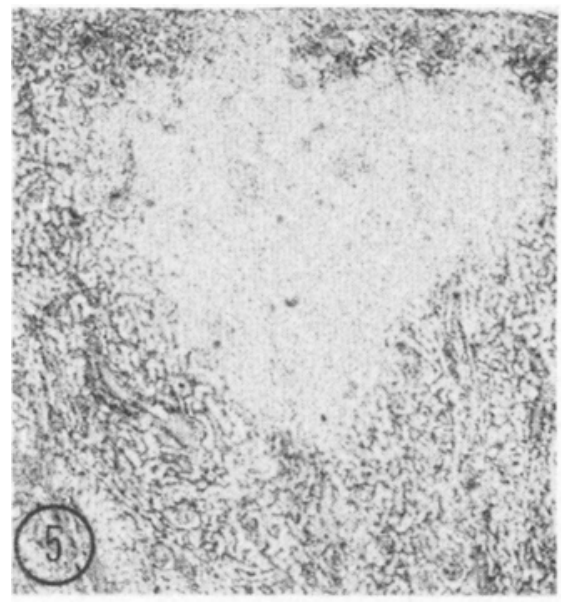

Figure 5. A renal infarct in a pig injected twice with Liquoid, and killed $24 \mathrm{hrs}$. after the last injection. Total dose: $40 \mathrm{mg}$ Liquoid/ kg body weight. $\mathrm{H} \& \mathrm{E}, \times 25$.

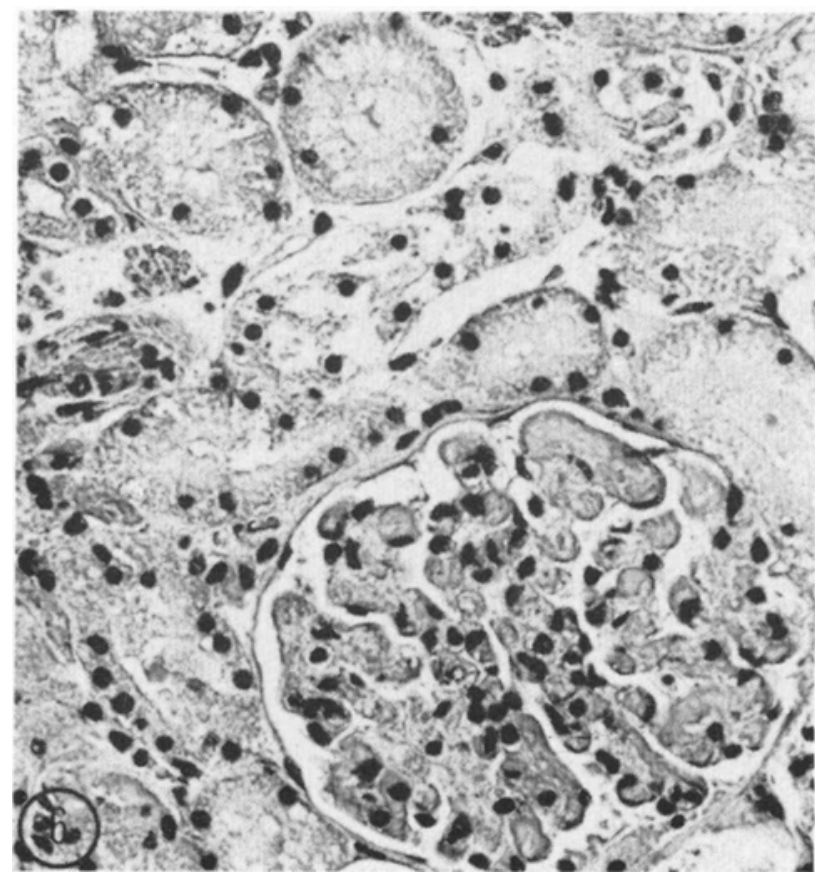

F ig u r e 6. A kidney section of a blue fox, died $18 \mathrm{hrs}$. after treatment; there are hyaline precipitations within glomerular capillaries, and early tubular degeneration, but not total parenchymal necrosis. Dose: $5 \mathrm{mg} \mathrm{Liquoid} / \mathrm{kg}$ body weight. $\mathrm{H} \& \mathrm{E}, \times 425$. 


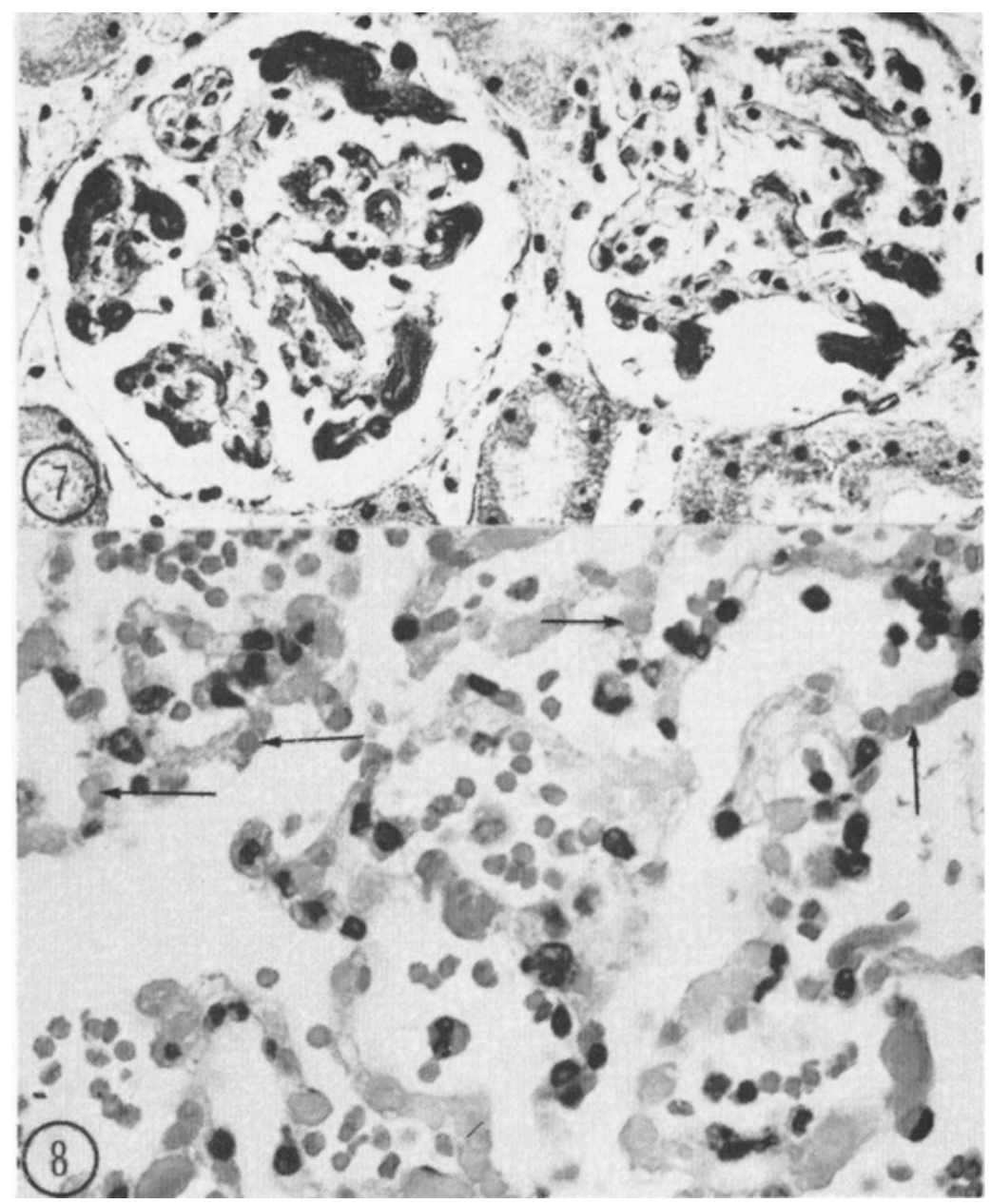

Figure 7. Glomerular "thrombosis"; same animal as in Fig. 6. MSB, $\times 425$.

Figure 8. Lung section from a blue fox, died $40 \mathrm{hrs}$. after treatment. Septal capillaries are occluded by a hyaline material in which individual erythrocytes may be discerned (arrows). There is extravasation of red cells into the alveoli. Dose: $12 \mathrm{mg} \mathrm{Liquoid} / \mathrm{kg}$ body weight. $\mathrm{H} \& \mathrm{E}, \times 640$. 


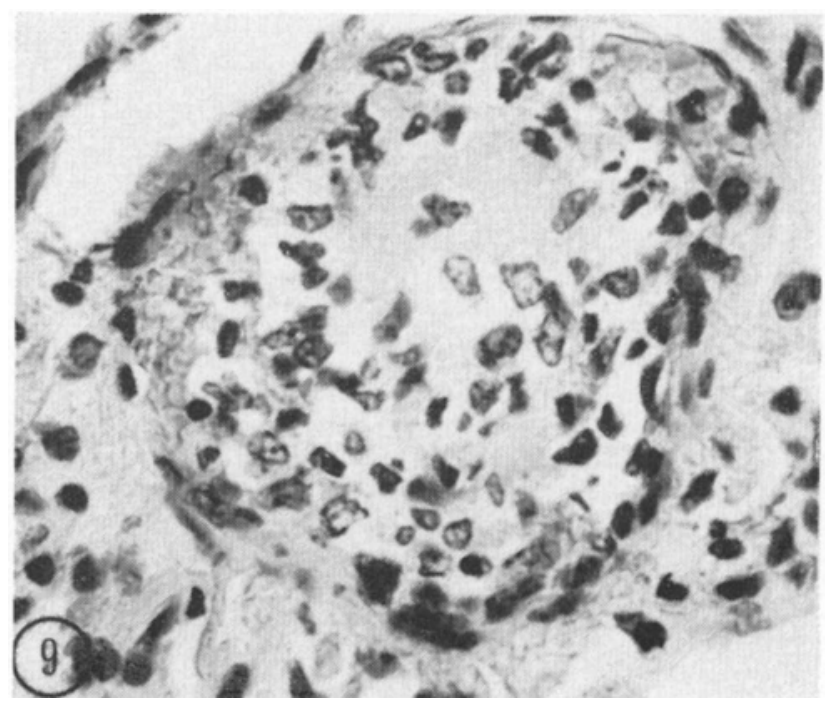

Figure 9. A thrombosed pulmonary artery with necrotic wall infiltrated by mononuclear cells. Same animal as in Figs. 6-7. $\mathrm{H} \& \mathrm{E}, \times 640$. 
Teige, J. jr., K. Nordstoga, M. Fjølstad \& I. Nafstad: The generalized Shwartzman reaction in pigs induced by diet and single injection of disintegrated cells or partially purified endotoxin from Escherichia coli. Acta vet. scand. 1973, 14, 92-106.

Thomas, L. \& R. A. Good: Studies on the generalized Shwartzman reaction. I. General observations concerning the phenomenon. J. exp. Med. 1952, 96, 605-624.

\section{SAMMENDRAG}

Liquoid-induserte arterie-forandringer og den generaliserte Shwartzman's reaksjon.

Ved intraven $\varnothing$ se injeksjoner av Liquoid ble det framkalt nekrotiserende forandringer $\mathbf{i}$ afferente nyrearterier hos kanin, gris og blårev. Forandringene var ledsaget av „mikrotromber“ i kapillærene i glomeruli, og ofte også av tromboseringer i de affiserte segmenter av arteriene. Karveggsforandringer var alltid tilstede når det forelå makroskopiske, nekrotiske forandringer i nyrebarken. Nekrotiserende forandringer med tromboseringer, ble observert i lungearterier hos alle dyrearter unders $\varnothing$ kelsen omfattet, dvs. kanin, gris, blårev, mus og fritte.

(Received July 13, 1977).

Reprints may be requested from: K. Nordstoga, the Department of Pathology, Veterinary College of Norway, P.O.Box 8146, Oslo Dep., Oslo 1, Norway. 